\title{
Penerapan Arsitektur Ekologis pada Bangunan Resort Tepi Pantai Karimunjawa
}

\author{
Kurniawati Fadhilah dan Muhammad Faqih \\ Departemen Arsitektur, Fakultas Arsitektur Desain dan Perencanaan, Institut Teknologi Sepuluh Nopember (ITS) \\ e-mail: faqih@arch.its.ac.id
}

\begin{abstract}
Abstrak-Kepulauan Karimunjawa merupakan salah satu kecamatan yang terletak di wilayah Kabupaten Jepara. Pariwisata di Kepulauan Karimunjawa mempunyai prospek yang baik dan masih dapat dikembangkan secara lebih optimal. Objek wisata yang beragam menjadi salah satu potensi dalam sektor pariwisata di Kepulauan Karimunjawa sehingga tergolong sebagai daya tarik dalam menghasilkan devisa negara. Keindahan yang menakjubkan dari pulau-pulau dan pantai-pantai yang terdapat di Karimunjawa diprediksi akan semakin diminati wisatawan domestik maupun mancanegara. Selain objek wisata yang beragam, Kepulauan Karimunjawa menawarkan keindahan alam salah satu diantaranya adalah Terumbu Karang. Pengembangan potensi daya guna lahan yang ada saat ini belum maksimal, hal ini terkait dengan belum terpenuhinya fasilitas akomodasi bagi wisatawan. Namun seiring meningkatnya kegiatan pariwisata dengan aktivitas yang tidak bertanggung jawab akan kelestarian lingkungan, secara langsung dapat memberi dampak buruk terhadap kerusakan terumbu karang. Pendekatan desain pada resort adalah arsitektur biomorfik yang mengambil ide-ide bentukan dari makhluk hidup di alam yang kemudian diterapkan pada rencana tapak. Kajian diawali dengan mempelajari pengertian dan hal-hal mendasar mengenai resort, tipe dan syarat hotel, sejarah dan perkembangan hotel, pedoman perencanaan hotel resort dan tinjauan arsitektur biomorfik. Berdasarkan keseluruhan aspek-aspek tersebut dapat saling mempengaruhi dalam menghasilkan perancangan resort dengan konsep arsitektur ekologis. Konsep Ekologis diwujudkan dengan perancangan resort yang memperhatikan lingkungan, melalui pola tatanan massa bangunan, konsep penghawaan dan pencahayaan bangunan, pemilihan material yang ekologis serta sistem sanitasi pada resort. Resort difasilitasi dengan laboratorium terumbu karang sebagai sarana penelitian bagi para peneliti dan pecinta alam.
\end{abstract}

Kata Kunci-Eco-Resort, Biomorfik, Terumbu Karang.

\section{PENDAHULUAN}

$\mathrm{W}$ ILAYAH pesisir dan lautan merupakan kawasan yang menyimpan kekayaan sumberdaya alam yang sangat berguna bagi kepentingan manusia. Secara mikro sumberdaya kawasan ini dipergunakan untuk memenuhi kebutuhan hidup esensial penduduk sekitarnya sedangkan secara makro, merupakan potensi yang sangat diperlukan dalam rangka menunjang kegiatan pembangunan nasional disegala bidang. Untuk itu keberadaan potensi sumber daya alam hayati dan non hayati di wilayah ini, perlu dikelola dan dimanfaatkan secara bijaksana sehingga dapat lestari dan berkesinambungan.

Salah satu potensi sumberdaya alam hayati yang sangat potensial di daerah pesisir adalah keindahan terumbu karang. Ekosistem terumbu karang merupakan bagian dari ekosistem

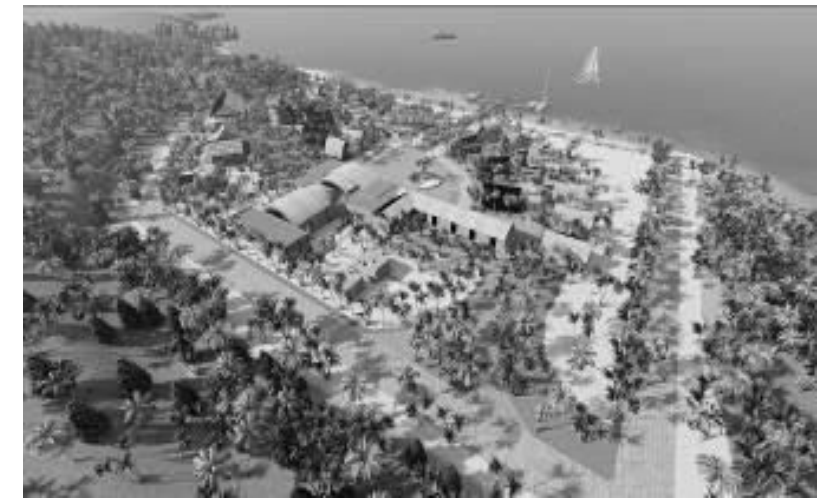

Gambar 1. Perspektif mata burung.

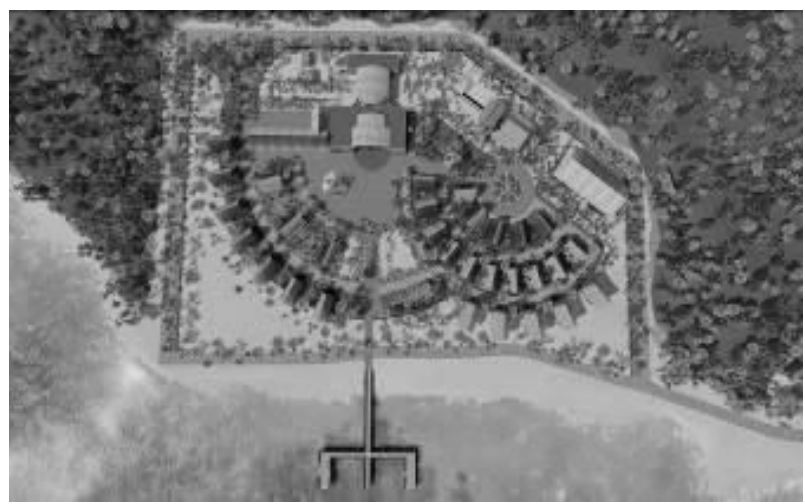

Gambar 2. Site plan

laut yang menjadi tempat kehidupan bagi beraneka ragam biota laut. Di dalam ekosistem terumbu karang dapat hidup lebih dari 300 jenis karang, 2000 jenis ikan dan berpuluh puluh jenis molluska,crustacea, sponge, algae, lamun dan biota lainnya [1].

Sejalan dengan tingginya potensi keindahan alam di Indonesia yang secara langsung berdampak pada meningkatnya pariwisata dan devisa Negara. Kegiatan pariwisata tersebut membawa pula dampak buruk bagi lingkungan dengan banyaknya aktivitas wisatawan. Di mana aktivitas tersebut memiliki kecenderungan mematikan ekosistem terumbu karang.

Menurut Ministery of State for Environment dalam [2], luas terumbu karang di Indonesia $\pm 5000 \mathrm{~km}^{2}$ diperkirakan hanya 7 $\%$ terumbu karang yang kondisinya sangat baik, $33 \%$ baik, 46 $\%$ rusak, dan $15 \%$ dalam kondisi sangat kritis, sedangkan menurut Moosa dan Suharsono, secara umum kondisi terumbu karang di kawasan Indonesia bagian timur dari 31 lokasi hanya 9,80 \% dalam kondisi sangat baik, 29,55 \% dalam kondisi 


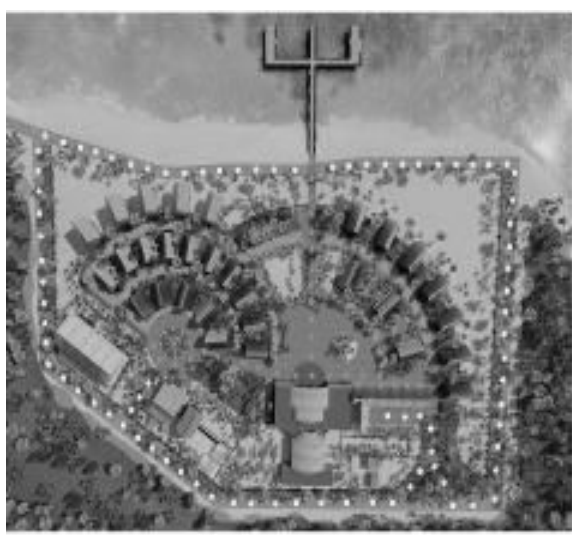

\section{SIRKULASI}

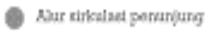
Aar sirkatad gongribla desersia
Gambar 3. Sirkulasi pengguna.
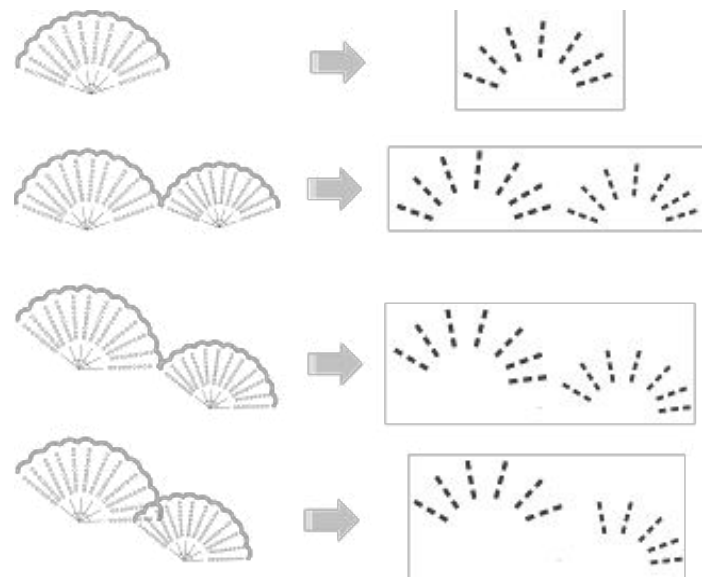

Gambar 4. Eksplorasi Biomorfik.

baik, 29,55 \% kondisi sedang dan sisanya 32,74\% dalam kondisi sangat buruk.

Di Taman Nasional Karimunjawa, Provinsi Jawa Tengah pada tahun 2011 terdapat beberapa aktivitas pariwisata yang kurang memiliki tanggung jawab dan dapat merusak lingkungan. Beberapa contohnya, wisatawan diperkenankan untuk mengambil foto di bawah laut dengan gaya memegang terumbu karang, selain itu wisatawan juga diperbolehkan untuk memberi makanan kepada ikan-ikan laut yang bertujuan untuk memanggil ikan-ikan tersebut agar dapat difoto. Ada kekhawatiran bahwa di objek-objek wisata bahari lain di Indonesia, khususnya pada kawasan konservasi atau taman nasional, terdapat indikasi yang sama terhadap lingkungan yang diakibatkan oleh aktivitas pariwisata.

Segala aktivitas atau kegiatan wisata, khususnya kegiatan wisata bahari yang tidak bertanggungjawab juga dapat mengancam kelestarian hidup makhluk hidup laut dan lebih jauh lagi dapat merusak objek wisata itu sendiri. Ancaman terhadap kelangsungan hidup terumbu karang, mengakibatkan kerusakan lingkungan yang besar. Terumbu karang yang merupakan sentral dari ekosistem laut sangat mempengaruhi kehidupan di laut. Komposisi oksigen di laut menjadi berkurang. Banyak biota laut, baik hewan maupun tumbuhan akan ikut musnah jika terumbu karang menjadi rusak. Selain itu, di daerah-daerah pesisir pantai akan mudah terjadi abrasi,
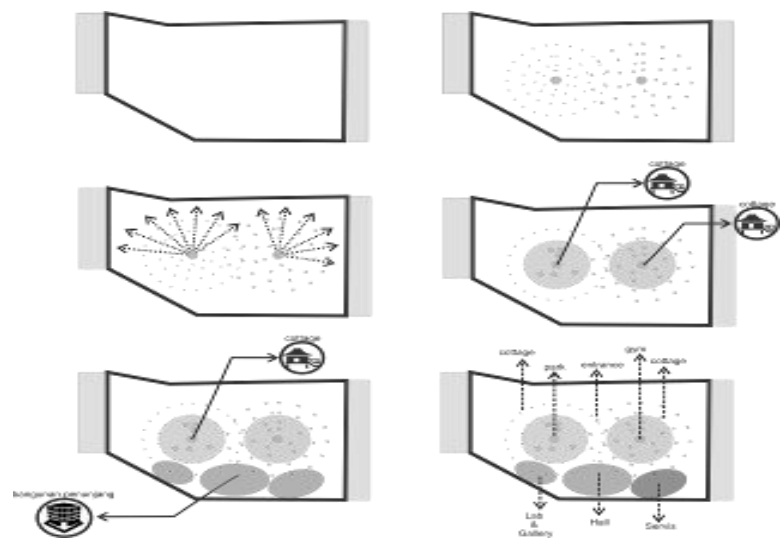

Gambar 5. Eksplorasi Zoning Site plan.
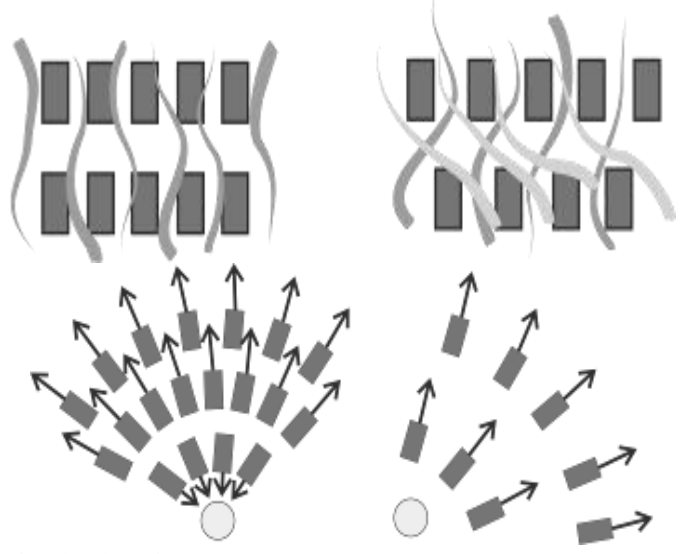

Gambar 6. Eksplorasi tatanan massa.

mengakibatkan perubahan lingkungan yang drastis dan membuat tidak adanya perlindungan terhadap daerah pantai. Berbagai pencemaran yang terjadi bukan hanya merusak laut tapi juga mengancam kesehatan manusia. Untuk itu diperlukan suatu perancangan arsitektur yang bersifat ekologis dan mengedukasi wisatawan.

Fasilitas tersebut dapat berupa suatu eco-resort yang dirancang untuk menjadi suatu destinasi wisata bahari dengan wawasan eko-wisata, sehingga wisatawan dapat tetap menikmati keindahan alam tanpa kekhawatiran adanya indikasi pengrusakan terumbu karang pada kawasan tersebut.

\section{METODA PERANCANGAN}

\section{A. Pendekatan Desain}

Konsep perancangan resort melalui pendekatan eco-design ini merupakan pengembangan resort yang memanfaatkan kondisi kekayaan alam tanpa adanya indikasi pengrusakan lingkungan. Penggunaan pendekatan ini secara langsung mengajak pengunjung resort, staff resort dan penduduk lokal sekitar untuk bertanggung jawab terhadap alam dalam melestarikan lingkungan dengan memberikan pengalaman pribadi dan meningkatkan kesadaran masyarakat akan pentingnya lingkungan.

Pada penerapannya eco-design membentuk resort yang 


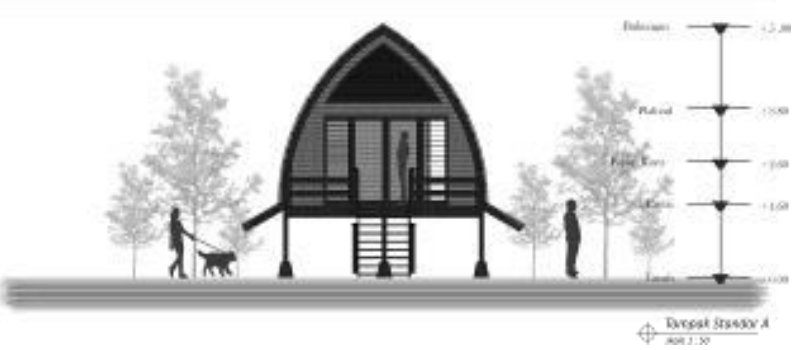

Gambar 7. Tampak depan Cottage type standar.

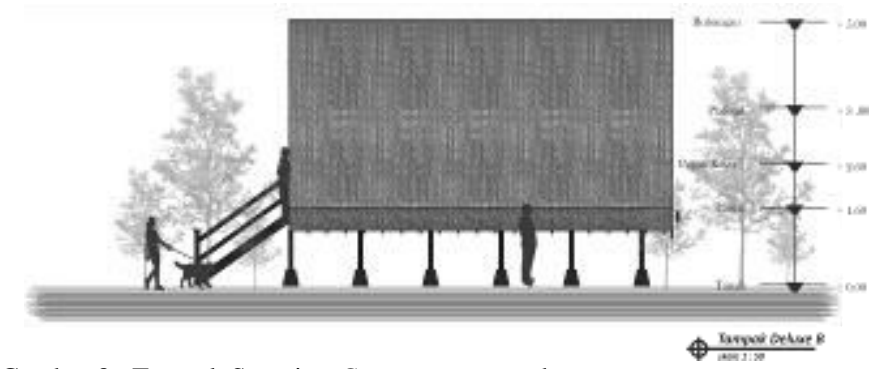

Gambar 8. Tampak Samping Cottage type standar.

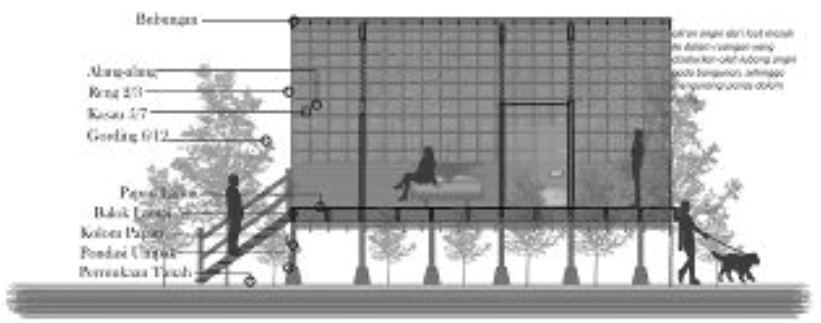

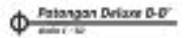

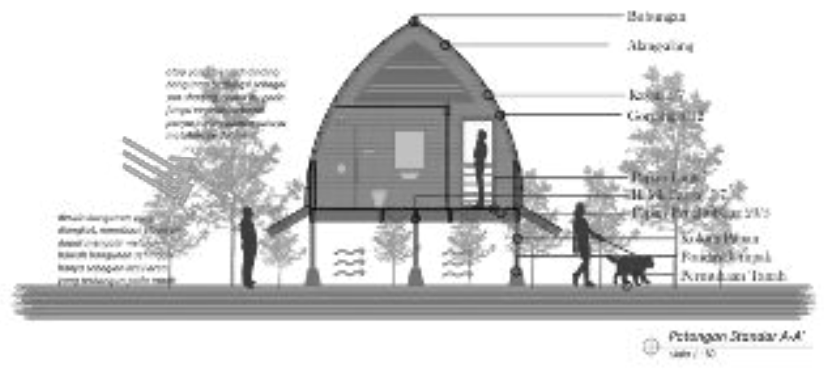

Gambar 9. Potongan Cottage type standar dan Penerapan Konsep ekologis Cottage.

mampu mewadahi kebutuhan eco-tourist dengan bentuk ruang yang memberikan pengalaman dalam hal environtment awareness, selain itu desain pada resort dapat menerapkan sustainable development dan green architecture dalam pembangunan maupun pengembangan resort.

\section{B. Proses Desain}

Berdasarkan buku Architecture Programming karya Donna P. Duerk, dikatakan proses suatu desain dalam memecahkan isu suatu permasalahan secara arsitektural melalui beberapa tahapan. Yaitu pencarian fakta, penentuan suatu isu, penetapan tujuan, kebutuhan tampilan pada sebuah rancangan dan pembuatan konsep.

Pencarian fakta diambil dari fenomena yang terjadi pada suatu lokasi, yaitu kerusakan terumbu karang akibat aktivitas

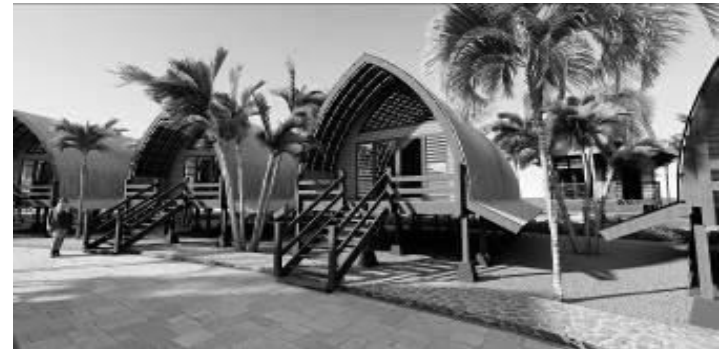

Gambar 10. Perspektif Cottage type standar.
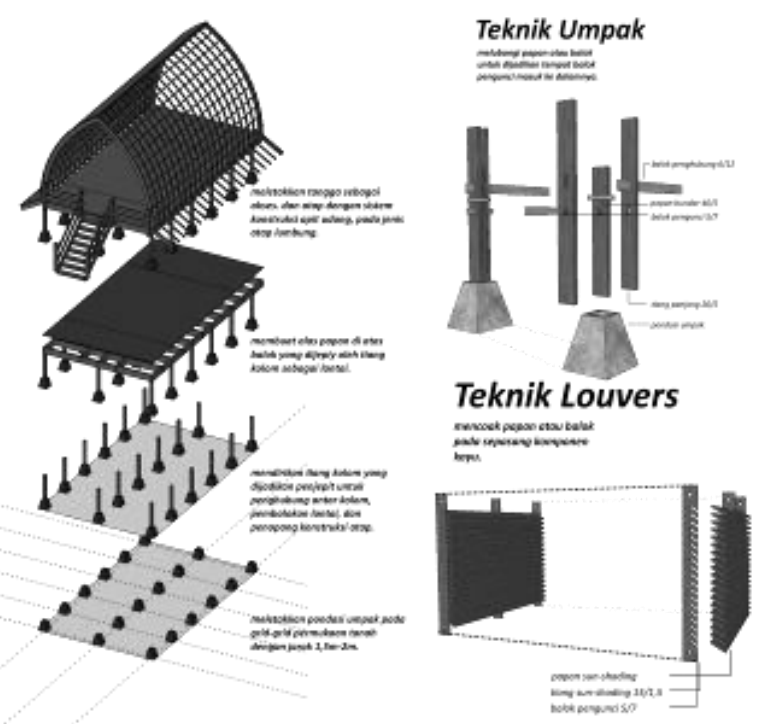

Gambar 11. Skema konstruksi.

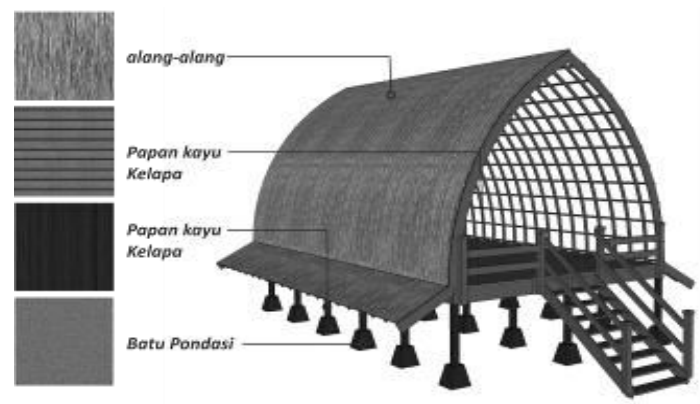

Gambar 12. Material Cottage.

manusia. Kemudian penentuan isu dapat difokuskan pada lokasi lahan yang diambil, yaitu Pulau Menjangan Kecil Karimunjawa. Dari penentuan isu tersebut, dapat ditetapkan tujuan yang ingin dicapai dari permasalahan yang ada di Pulau Menjangan Kecil Karimunjawa, seperti mengurangi dampak kerusakan yang terjadi pada terumbu karang yaitu dengan mendirikan suatu bangunan yang didesain secara ekologis di mana bangunan tersebut memberi respon arsitektural terhadap permasalahan yang ada serta dapat menumbuhkan kepekaan terhadap kepedulian lingkungan sehingga megurangi aktivitas pengrusakan terhadap terumbu karang. Dalam mencapai tujuan tersebut diperlukan beberapa kebutuhan tampilan dalam sebuah rancangan yaitu merancang resort yang mampu meningkatkan kepekaan lingkungan pada wisatawan khususnya para pemerhati lingkungan. Dengan demikian dapat 


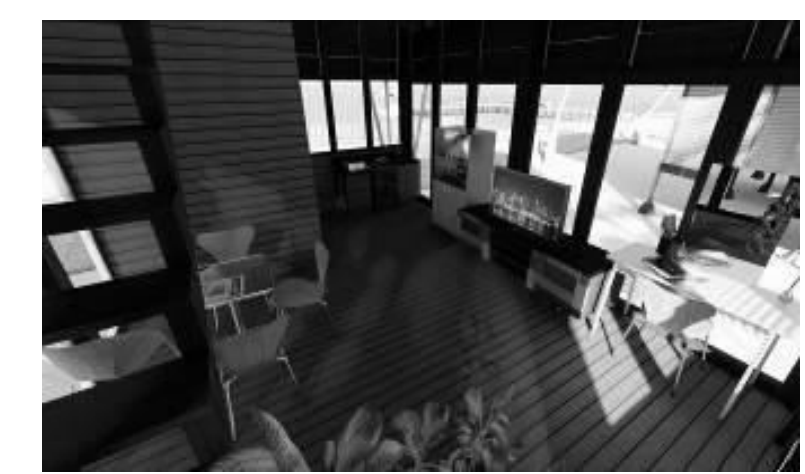

Gambar 13. Ilustrasi ruang dalam Cottage.

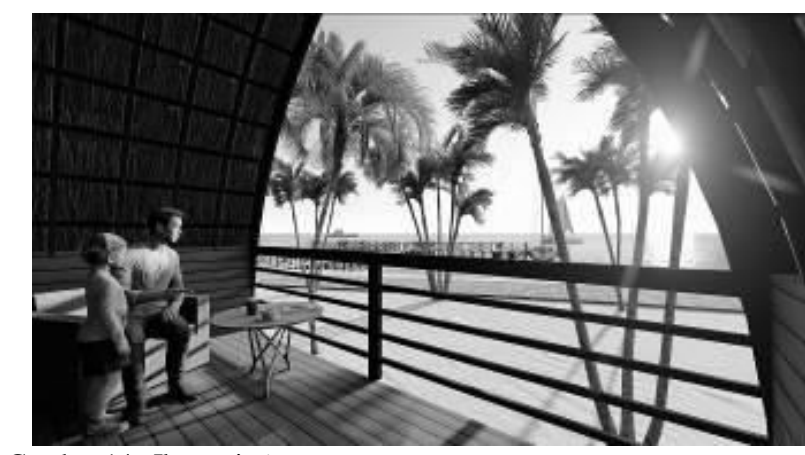

Gambar 14. Ilustrasi view teras.

muncul konsep rancang berupa eco-tourist resort.

\section{Metode Desain}

Arsitektur biomorfik merupakan salah satu pemaknaan dari arsitektur organik. Dalam dunia arsitektur, arsitektur biomorfik muncul dari pemikiran akan pentingnya berorientasi ke alam beserta lingkungannya, yang kemudian melahirkan suatu aliran baru, yakni aliran biotektur (arsitektur biologi). Aliran ini berpendapat bahwa alam sendiri adalah konstruksi yang ideal dalam arsitektur. Kemudian aliran biotektur berkembang menjadi arsitektur biomorfik dimana keadaan alam dapat di manfaatkan sebagai contoh desain untuk bangunan yang menggunakan prinsip struktur dan motif dari alam.

Biomorfik menekankan pada proses terbentuknya dan pembentukan wujud-wujud arsitektural. Peter Collins menekankan pada hakekat-hakekat pengibaratan biologikal atau lebih khusus pada kesejajaran yang ada antara organismeorganisme yang ada di alam dengan arsitektur, kemudian disajikan pula ketidaksejajaran antara organisme di alam dengan arsitektur. Dalam proses pembentukan ada dua ibaratan biologikal, yaitu: Organik dan Biomorfik. Keduanya memberikan penekanan pada proses yang dijalani oleh suatu organisme di alam yang hidup.

Dalam organisme yang hidup ada unsur yang menandai kehidupannya, yaitu:

1. Memiliki struktur susunan yang teratur dan tertentu.

2. Pentautan antara struktur itu dan bentuk atau wujud organisme dalam fungsi organisme (Structure, form, function).

3. Function, Life Form within (Kaitan fungsi dan kehidupan).

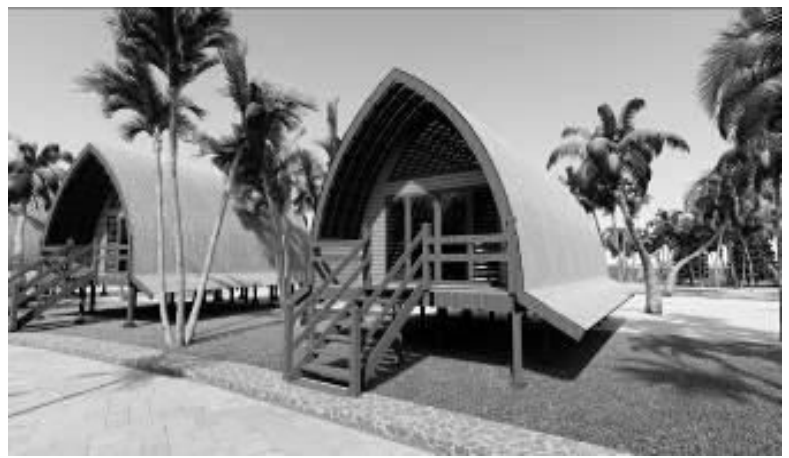

Gambar 15. Ilustrasi perspektif Cottage.

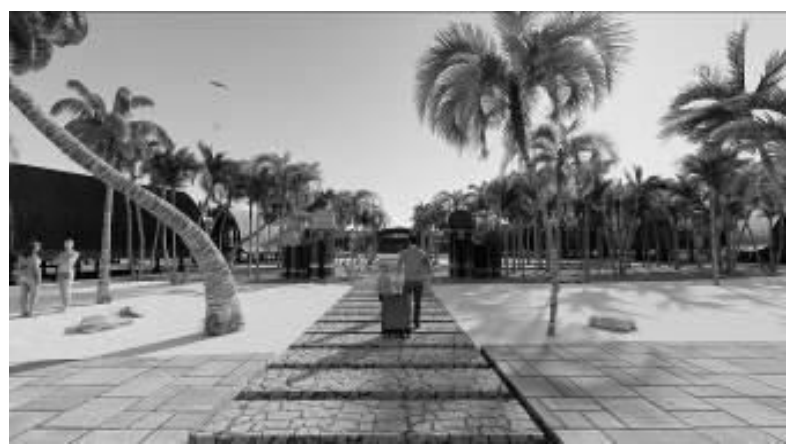

Gambar 16. Ilustrasi view gerbang resort.

\section{HASIL DAN KSPLORASI}

\section{A. Konsep Gubahan Massa}

Desain Perancangan Eco Resort Tepi Pantai Kep. Karimunjawa ini menggunakan metode arsitektur biomorfik yang mendasari bentukkan dari alam dan makhluk hidup. Oleh karena itu, bentuk tatanan massa bangunan pada perancangan mengadaptasi dari bentuk kerang.

\section{B. Konsep Arsitektur Tropis}

Arsitektur tropis merupakan arsitektur yang berada di daerah tropis. Kep. Karimunjawa berada pada area beriklim tropis yang memberikan pengaruh yang cukup signifikan terhadap bentuk bangunan. Kondisi iklim seperti temperatur udara, radiasi matahari, angin, kelembaban, serta curah hujan, mempengaruhi desain.

Berikut ciri-ciri dari penerapan arsitektur tropis:

1. Memiliki atap dengan bubungan tinggi

2. Mempunyai tritisan / overstek atap

3. Mempunyai lubang untuk ventilasi secara silang

4. Sistem rumah panggung

5. Menggunakan material alam

\section{Orientasi Bangunan}

Orientasi bangunan beriklim tropis dipengaruhi arah edar matahari, yaitu selatan-utara dengan bangunan yang berada di barat-timur [3]. Sedangkan orientasi bangunan terhadap arah angin harus tegak lurus terhadap arah datangnya angin.

Namun pada keadaan existing, orientasi yang baik untuk memanfaatkan view potensial pantai berlawanan dengan orientasi matahari. Oleh karena perancangan merupakan bangunan komersial yang memberikan kenyamanan dan 


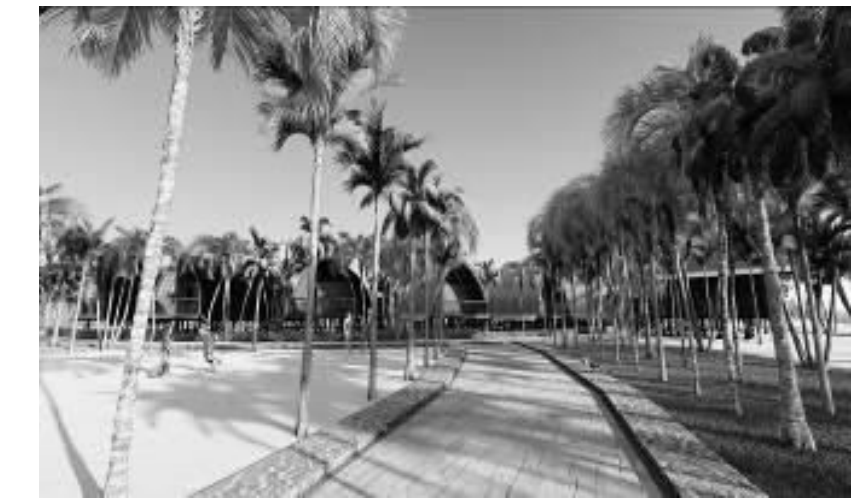

Gambar 17. Ilustrasi view resort.

memanjakan mata pengguna maka view ke arah laut dipilih sebagai view utama dalam daya tarik yang ditawarkan dari perancangan resort.

\section{Tatanan Massa Bangunan}

Pada perancangan dengan pendekatan ekologis, kenyamanan termal menjadi peran yang penting. Dengan penataan massa yang tepat, kenyamanan termal dapat dicapai dengan memaksimalkan aliran angin yang masuk ke dalam bangunan [4]. Pola tatanan massa yang tepat untuk resort adalah tatanan cluster.

Di mana pola tatanan cluster akan memberikan banyak sisi bangunan yang dilewati aliran angin dan sirkulasi angin silang yang cukup baik.

\section{E. Material Bangunan}

Penggunaan material pada perancangan erat kaitannya dengan tujuan hemat energi dan ramah lingkungan. Untuk itu digunakan material hijau atau material ramah lingkungan.

Prinsip material ekologis yaitu [5],

1. Renewable resources (sumber daya yang terbarukan)

2. Low energy process (diproses dengan sedikit energi)

3. Local ability (diproduksi di daerah tersebut)

4. Recycle content (dapat didaur ulang)

5. Remanufacture (dapat diproduksi kembali)

Dengan demikian material yang digunakan dalam

perancangan adalah kayu kelapa sebagai material keseluruhan bangunan. Dan dikombinasikan dengan material alam yaitu grass block, paving block, paving stone, pasir pantai. Sesuai dengan fungsi kebutuhan bangunan.

\section{KESIMPULAN}

Dari pembahasan yang telah diuraikan, dapat disimpulkan bahwa dengan adanya objek rancangan Eco Resort Tepi Pantai di Kep. Karimunjawa ini dapat memberikan wadah atau sarana bagi wisatawan/pengunjung di Karimunjawa pada umumnya

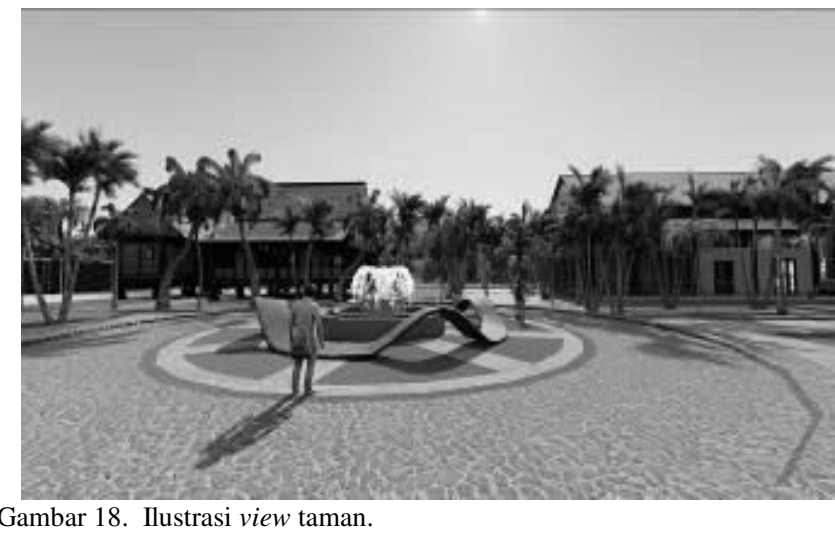

dan Pulau Menjangan Kecil pada khususnya yang ingin beristirahat saat mengunjungi tempat-tempat wisata di Karimunjawa.

Dengan adanya sarana laboratorium pada perancangan, para pengunjung serta khususnya para peneliti dan pecinta alam dapat memanfaatkan sarana tersebut dalam melakukan penelitian. Selain itu juga dapat dijadikan tempat tujuan berekreasi sekaligus ikut serta membudidaya terumbu karang.

Implementasi Arsitektur Biomorfik merupakan tema yang digunakan di mana tatanan massa, pemilihan material dan warna diambil dari ide-ide bentukan yang terdapat di alam ataupun makhluk hidup dan diterapkan pada objek rancangan. Dengan demikian objek rancangan akan memiliki unsur-unsur Biomorfik.

Perancangan juga memberikan kesempatan bagi daerah pariwisata lokal dan masyarakat setempat dalam mengembangkan potensi daerah maupun individu guna menunjang pendapatan daerah di sektor pariwisata. Dengan adanya perancangan resort ini dapat memberi kesempatan pengalaman eko-wisata salah satunya dengan ikut membudidayakan terumbu karang untuk memperkaya pengetahuan dan pentingnya ekosistem tersebut dalam alam. Sehingga para pengunjung atau wisatawan tidak hanya dapat berekreasi dan relaksasi tapi juga dapat melihat potensi yang ditawarkan di Karimunjawa sekaligus memelihara alam sekitar.

\section{DAFTAR PUSTAKA}

[1] R. Dahuri, Keanekaragaman Hayati Laut. Aset Pembangunan Berkelanjutan Indonesia. Jakarta: Gramedia Pustaka Utama, 2003.

[2] Supriharyono, Pelestarian dan pengelolaan Sumber Daya Alam di Wilayah Pesisir Tropis. Jakarta: Gramedia Pustaka Umum, 2000.

[3] G. Lippsmeier, Bangunan Tropis. 1997: Erlangga, 1997.

[4] Z. Bomberek, "Eco-Resorts : Planning and Design for the Tropics," 2009.

[5] B. Subiyanto, "Bahan Bangunan Ramah Lingkungan (Green Building Material)," Jakarta, 2010. 